\title{
SUPPRESSION OF SEGREGATION AND CONTROL OF THE STRUCTURE OF INGOTS AND CASTING
}

\author{
V.O. Shapovalov, G.M. Grigorenko, Yu.O. Nikitenko, V.V. Yakusha, E.V. Shapovalov \\ E.O. Paton Electric Welding Institute of NAS of Ukraine, \\ Kiev, Ukraine \\ E-mail: shapovalov@paton.kiev.ua,tel.+38(044)200-60-57
}

The problem of segregation in large ingots, which are used in energy, heavy engineering, etc., is considered. A new approach to suppressing segregation processes is proposed. It consists in regulating the local crystallization time by organizing a surfaced local metal bath on the surface and adjusting the speed of its movement, while an ingot is formed layer by layer.

\section{INTRODUCTION}

In connection with the increase in the size of products for traditional and nuclear energy, heavy and petrochemical engineering, as well as the militaryindustrial complex, the demand for large and extra-large high-quality ingots and forging blanks is growing. The mass of ingots can reach several tens and hundreds of tons [1]. The quality of the ingots is determined by the number of shrinkage and segregation defects associated with a specific production method. With an increase in the size of ingots, the degree of alloying significantly deteriorates their quality. The axial porosity and volume of the shrinkage cavity shell increase. The number of endogenous and exogenous inclusions varies significantly in size and distribution over the cross section of the ingot. Inclusions can increase in size and accumulate in separate areas of the ingot. This significantly affects the homogeneity and uniform distribution of properties over the cross section of the ingot $[2,3]$. To ensure the corresponding properties and especially homogeneity structure over the entire cross section of the ingot, only part of the ingot is used, which reduces the yield. But the part of the ingot that is used and has satisfactory properties also decreases in percentage terms with an increase in its size.

Therefore, increasing the chemical and physical homogeneity of ingots and castings is of priority importance.

The main reasons that must be overcome to improve the quality of cast metal are two: metal contamination by non-metallic inclusions and crystallization processes. The first reason metallurgists managed to overcome through the use of after-furnace treatment. Today, metal after out-of-furnace treatment can have a total amount of impurities of not more than $50 \mathrm{ppm}$. They are still trying to overcome another reason related to crystallization phenomena. To do this, apply:

- vibration,

- ultrasound,

- electromagnetic effect,

- regulation of the temperature of the liquid metal,

- regulation of the thermal field on the surface of the bath,

- the introduction of refrigerators and the like.
But significant achievements, especially in field the crystallization of large ingots, are not yet available. The main reason is the uncontrolled crystallization rate.

During crystalization of metals, a first-order phase transition occurs. It is inherent in such a phenomenon as segregation. Segregation during crystallization of metals and alloys is associated with different solubilities of elements in solid and liquid phases [4]. The ratio of element concentrations in phases is determined by the distribution coefficient in the equilibrium stage [4]. Deviation from equilibrium leads to a change in the coefficient. In real conditions, it is necessary to talk about the effective coefficient of the distribution of elements in the solidification of metal [5], which can be calculated by the formula

$$
K=\frac{K_{0}}{K_{0}+\left(1-K_{0}\right) e^{-f \delta / D}},
$$

where $f-$ is the crystallization rate, $\mathrm{cm} / \mathrm{s} ; \delta-$ is the thickness of the diffusion layer adjacent to the crystallization front and enriched with impurities, cm; $D$ is the diffusion coefficient of the impurity, $\mathrm{cm}^{2} / \mathrm{s}$.

As the crystallization rate increases, the effective coefficient approaches its value to one. In this case the segregation should be suppressed. In real conditions, especially when the ingots or castings are large in size (mass), increasing the rate or reducing the local crystallization time is very difficult. This also applies to the remelting processes of EBR, PAR and ESR. When the ingot has a diameter at the intersection greater than the critical one, the segregation phenomena become uncontrollable.

\section{PURPOSE OF THE STUDY}

Development of a method for suppressing segregation, regardless of the size of ingots and cast products. To achieve the goal, we proposed to change the way the ingot is formed, for example, in the case of PAP, replacing a large metal bath with a local one that moves at high speed. In this case, an additional outflow of heat from the end surface not covered by the bath appears, Fig. 1. It becomes possible to set the crystallization rate, respectively suppress segregation and control the structure of the ingot. 

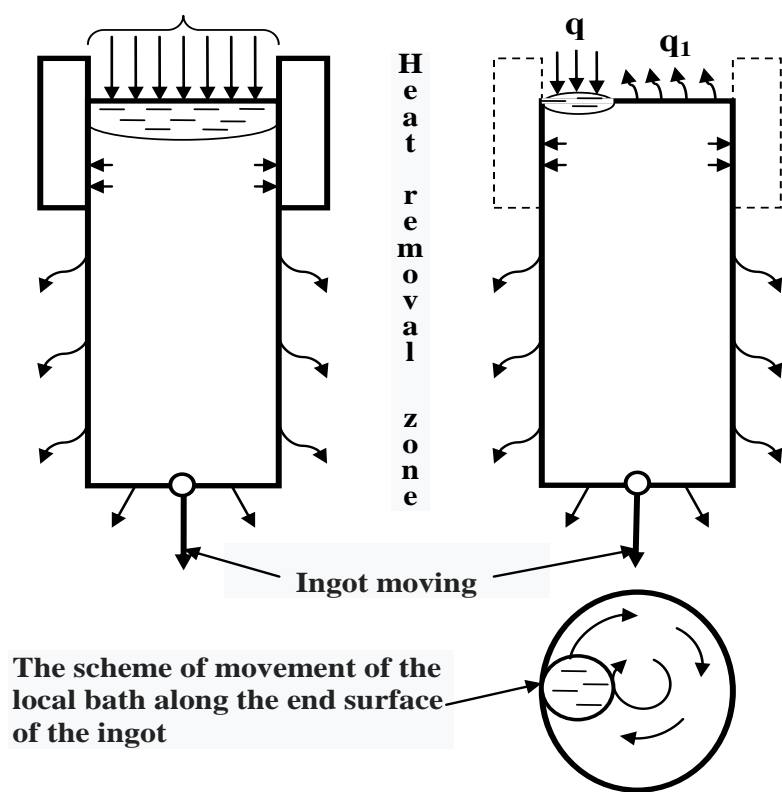

Fig. 1. Heat distribution when production ingots by different technologies

\section{EXPERIMENT CONDITIONS}

An ingot was smelted to verify the proposed approach under laboratory conditions. A local bath was formed using an arc heating source and moved at a speed of $3 \mathrm{~mm} / \mathrm{s}$. The arc current was $150 \mathrm{~A}$, and the arc voltage was $19.4 \mathrm{~V}$. Welding wire with a diameter of $1.2 \mathrm{~mm} \mathrm{08G2S}$ was used as a consumable.

\section{THE DISCUSSION OF THE RESULTS}

A macro section of the vertical section of the ingot and a metal selection map for research are presented in Fig. 2.

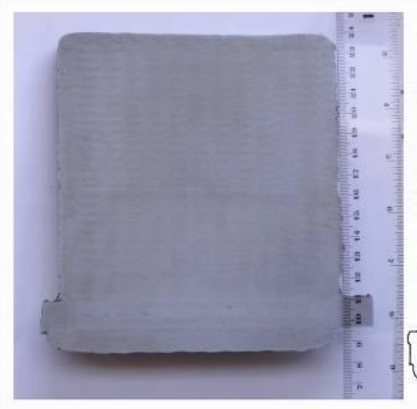

$a$

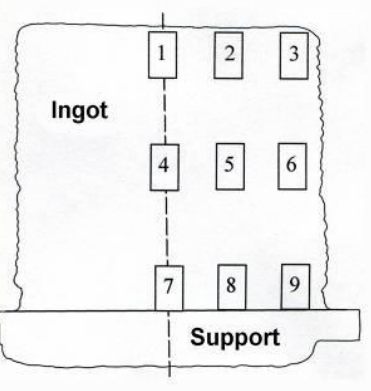

$b$
Fig. 2. Macrosection of the ingot (a) and sampling scheme $(b)$

As follows from the figure, the macrostructure of the ingot is homogeneous and fine-grained. Further investigation of the microstructure of the samples taken at points 1-9 showed that grains in size correspond to 8-9 numbers, Fig. 3. The above results show that the creation of stable conditions for the formation of the ingot eliminates the scale factor and extends the results to almost any size ingots. The obtained large ingots can be used without removing the head and bottom parts. At the same time, the weight of especially large ingots can be reduced with the same loads on the products that will be made from these ingots, due to the equality to the unit coefficient, which takes into account the scale factor, and an increase in strength due to both the absence of zonal segregation and a decrease in the level of dendritic segregation.

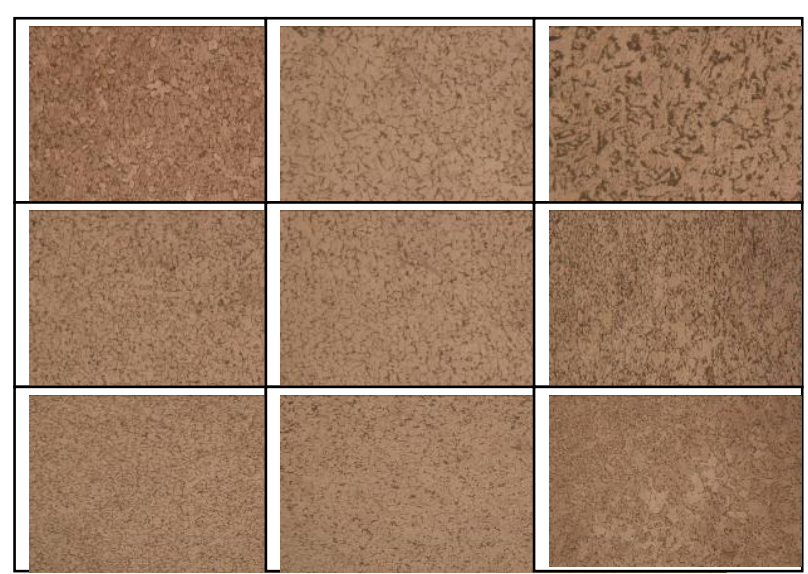

Fig. 3. Photos of microsections. Magnification 200.

The arrangement of photographs corresponds to the scheme in Fig. 2,b

As measurements showed strength, toughness and other mechanical characteristics increased by $10 \ldots 50 \%$ compared with the characteristics of the same grade of metal obtained by traditional technology, Table.

\begin{tabular}{|c|c|c|}
\hline 08G2S & Source metal & Ingot \\
\hline $\begin{array}{c}\text { Tensile strength, } \\
\mathrm{MPa}\end{array}$ & 441.5 & 497.7 \\
\hline $\begin{array}{c}\text { Yield strength, } \\
\mathrm{MPa}\end{array}$ & 304.1 & 359.5 \\
\hline $\begin{array}{c}\text { Relative } \\
\text { extension, \% }\end{array}$ & 21 & 37.5 \\
\hline $\begin{array}{c}\text { Impact strength, } \\
\mathrm{J} / \mathrm{cm}^{2}\end{array}$ & - & 227.9 \\
\hline
\end{tabular}

This is especially important for products from highly alloyed alloys operating in extreme conditions. The proposed approach is a way to obtain large ingots with properties and structure that cannot be obtained using traditional technology. Further testing of products from such ingots in real conditions will confirm or refute the appropriateness of the proposed approach.

\section{REFERENCES}

1. Отчет о мировом форуме производителей крупных поковок. Сантандер, Испания, 3-7 нояб., 2008, c. 11-19.

2. Ю.А. Нехензи. Стальное литье. М.: ГИНТЛ по черной и цветной металлургии, 1948, 766 с.

3. А. Митчел, А.С. Бэлэнштайн. Факторы, влияющие на температуру и кристаллизацию слитков при ЭШП // Электрошлаковый переплав. 1985 , в. 6 , с. $192-198$.

4. М. Флемингс. Процессы затвердевания: Пер. с англ. / Под ред. д.т.н. А.А. Жукова и д.т.н. Б.В. Рабиновича. М.: «Мир», 1977, 424 с.

5. Технология полупроводниковых материалов / Под ред. Г. Бриджерса, Дж. Скаффа, Дж. Шайва и Ф. Бионди / Пер. с англ. / Под ред. М.И. Иглицына. М.: «Оборонгиз», 1961, 314 с. 


\section{ПОДАВЛЕНИЕ ЛИКВАЦИИ И УПРАВЛЕНИЕ СТРУКТУРОЙ СЛИТКОВ И ЛИТЫХ ИЗДЕЛИЙ}

\section{В.А. Шаповалов, Г.М. Григоренко, Ю.А. Никитенко, В.В. Якуша, Е.В. Шаповалов}

Рассмотрена проблема ликвации в крупных слитках, которые используются в энергетике, тяжелом машиностроении и др. Предложен новый подход к подавлению ликвационных процессов. Он заключается в регулировании локального времени кристаллизации путем организации на поверхности наплавляемой локальной металлической ванны и регулировании скорости ее перемещения, при этом слиток формируется слой за слоем.

\section{ПРИГНІЧЕННЯ ЛІКВАЦІЇ ТА УПРАВЛІННЯ СТРУКТУРОЮ ЗЛИТКІВ І ЛИТИХ ВИРОБІВ}

В.О. Шаповалов, Г.М. Григоренко, Ю.О. Никитенко, В.В. Якуша, С.В. Шаповалов

Розглянуто проблему ліквації в крупних злитках, які використовуються в енергетиці, важкому машинобудуванні тощо. Запропоновано новий підхід щодо пригнічення лікваційних процесів. Він полягає в регулюванні локального часу кристалізації шляхом організації на поверхні, що наплавляється, локальної металевої ванни і регулюванні швидкості ії переміщення, при цьому злиток формується шар за шаром. 